\title{
Manganese: Sources and Beneficiation
}

$\mathbf{R}^{2}$ USSIA was the United States' Number One source of manganese ore in 1948 when 34 pct of imports were received from that source, stated Norwood B. Melcher, assistant chief, ferrous metals and alloys branch, Bureau of Mines. In 1949, this country received only 20 pct of 1948 shipments from Russia, and only token amounts are now being received. Aggressive programming by industry and government resulted in prompt increases in shipments from major producing sources; India, Gold Coast, and the Union of South Africa all increased exports to fill the vacuum left by Russia and provided an excess adequate to increase total imports approximately 290,000 short tons in 1949. Again in 1950, and with even less ore from Russia, imports increased another 290,000 short tons. Since the shift from Russia as a source of manganese, the United States has received in total about 85 pct of its imports from India, Union of South Africa, Gold Coast, and Brazil in that order of importance.

Producers of both home-consumed and merchant ferromanganese have been able to adjust downward the manganese content of the home-consumed product and so obtain partial relief. Millions of tons of steel were produced in 1951 with a relatively low grade ferromanganese. This adjustment has been made without decreasing the quality of the steel, although with some increase in cost through introduction of new problems, including increased handling of material and additional removal of carbon.

Forced into a pattern of price and grade structure such as exists today, the producer of ferromanganese must adopt one of three possible courses as a shortrange program: $1-\mathrm{He}$ may continue to deplete his stocks by producing standard (78 pct) ferromanganese and hope that the future will bring some form of relief; 2-he may attempt to produce 78 pct ferromanganese by paying higher prices for premium ores; or 3-he may drop the grade of ferromanganese and stretch stocks and future supplies of ore as far as possible.

The present rundown condition of Indian railroads is attributed to the fact that the service has had no opportunity to recuperate since the beginning of World War II, while the demand for the movement of commodities has probably increased.

The Union of South Africa has expanded its exports to the United States greatly since 1948, but the showing of that country in 1951 was disappointing. Efforts have been made for some time by firms in the United States, at the urging of the manganese miners in the Union, to prevail on the railroad authority to grant and make available larger allocations of cars for manganese ore movement. As a whole, such efforts have been unsuccessful. Although the allocation of rail shipping has been the obvious factor in the decreased movement of ore, many other less determinate factors appear to be involved.

Brazil, long an important supplier of manganese to the United States, has important manganese deposits in three areas, all of which are significant to this country.

The Gold Coast is an important source of supply. Its metallurgical ore is particularly of significance because of its unusually high grade which permits considerable latitude in blending with the lower grade materials of South Africa and India.

The Belgian Congo should have an output of 100,000 tons or more annually beginning this year.

R. S. Dean presented two papers. One with $K$. M. Leute on hydrometallurgical methods for recovery of manganese from domestic ores and one as sole author on the so-called carbamate or Dean process. The two papers tied into each other. In the first mentioned he reviewed the various processes applicable to oxidized, and nonoxidized and reduced ores. The advantages of each were pointed out.

So far the only process tried on a substantial scale on oxidized ores was the $\mathrm{SO}_{2}$ process used at Las Vegas, Nev., on Three Kids ore during World War II. Many problems were encountered. Some of them were whipped while some of those remaining perhaps would have been whipped had time permitted. Since then work has been done elsewhere to avoid the formation of the troublesome thionates encountered at the Three Kids plant. Dean discussed the thionate and $\mathrm{NO}_{2}$ processes as applied to oxidized ores.

The only commercially used process on reduced ores is that of making electrolytic manganese. Among others that have been considered are the nitric acid process, the Bradley-Fitch ammonium sulphate process, and Dean's ammonium carbamate process.

Dean's thesis was that extremely large tonnages of so-called low grade manganese ores are available, and that these should not be depleted in attempting to simulate a foreign metallurgical grade ore. He pointed out that the grade of the domestic manganese ores would be considered high if the same grade were found in copper ores. The selling price of electrolytic manganese and electrolytic copper are roughly the same.

In addition to electrolytic manganese, he believes that domestic ores should be used to make exceptionally high grade products. These might be battery grade oxide or substantially pure oxide sinter, which might be used for high manganese alloys or for upgrading metallurgical grade manganese to produce a high manganese ferroalloy.

The carbamate process is based on the fact that manganous oxide is readily soluble in concentrated ammonia solutions containing ammonium salts. In solutions of sufficiently high concentration the manganese exists as an anion. Lixiviants of ammonia and ammonium carbonate permit extraction of the manganese from reduced ores and the manganese can be recovered as carbonate by heating or by driving off ammonia.

R. V. Lundquist presented a paper on upgrading high-silica ores or concentrates with sodium hydroxide to extract silica and to yield a product with a more favorable manganese : silica ratio. The $\mathrm{NaOH}$ is regenerated in part by $\mathrm{CaO}$.

This timely session held on Tuesday morning, Feb. 19, 1952 at the AIME Annual Meeting was sponsored jointly by the Extractive Metallurgy Div. and the Minerals Beneficiation Div. J. H. Jacobs, U. S. Bureau of Mines, Boulder City, Nev., and John D. Sullivan, Battelle Memorial Institute, Columbus, were Associate Chairmen. 